ISSN: 2548-0723

\title{
Beden Eğitimi ve Spor Öğretmenliği Adaylarının Liderlik Özellikleri ile Sosyal Problem Çözme Becerileri Arasındaki İlişkinin İncelenmesi
}

\author{
Kenan KOÇ ${ }^{*}$ \\ ${ }^{1}$ Erciyes Üniversitesi Spor Bilimleri Fakültesi, Kayseri, https://orcid.org/0000-0002-1459-2655.
}

$\ddot{\mathbf{O} z}$

Orijinal Makale

$\mathrm{Bu}$ araştırmanın amacı; spor bilimleri fakültesinde öğrenim gören öğrencilerin liderlik özellikleri ile sosyal problem çözme becerileri arasındaki ilişkinin incelenmesidir. $\mathrm{Bu}$ amaç doğrultusunda çalışma grubuna Nevşehir Hacı Bektaşi Veli, Erciyes, Ahi Evran ve Dumlupınar Üniversitesinden 2017-2018 eğitim öğretim yılında beden eğitimi ve spor öğretmenliği programında 1. 2. 3. ve 4. sınıflarında öğrenim gören 300 gönüllü öğrenci katılmıştır. Araştırmada veri toplama aracı olarak Öğretmen Liderlik ölçeği (Beycioğlu ve Aslan, 2010), Sosyal problem çözme envanteri (Dora, 2003) ve Sosyodemografik bilgi formu kullanılmıştır. Ölçeklerden elde edilen puanlar bir istatistik programı ile analiz edilmiştir Adaylara ilişkin kişisel bilgiler ve envanter toplam puanları ortalamalar ve standart sapma puanları tespit edilerek verilmiştir. Ölçeklerden elde edilen puanların arasındaki ilişkiyi ortaya koyabilmek için Pearson Momentler Çarpımı Korelasyon analizi (r) ve elde edilen puanlarının birbirinin yordayıcı olup olmadığını tespit edebilmek için Çoklu regresyon analizi ( $\beta)$ uygulanmıştır. Sonuç olarak liderlik ile probleme olumlu yönelim alt boyutu arasında ileri düzeyde pozitif ilişkiler saptanırken, probleme olumsuz yönelim, dürtüsel/dikkatsiz tarz ve kaçınan tarz alt boyutlarında negatif yönde ilişki olduğu tespit edilmiştir. Eğitim ortamlarında liderlik özelliklerini pekiştirmeye yönelik planlanan çalışmaların sosyal problemleri çözme açısından öğrencileri daha donanımlı bir hale getirebileceği söylenebilir.

\section{Investigation of The Relationship Between Leadership Characteristics and Social Problem Solving Skills of The Physical Education and Sports Teacher Candidates}

\begin{abstract}
The aim of this study is to examine the relationship between leadership skills and social problem solving skills of students studying at the faculty of sports sciences. For this purpose, 300 volunteer students from Nevşehir Haci Bektas Veli, Erciyes, Ahi Evran and Dumlupinar University 1st, 2 nd, 3rd and 4th grades of physical education and sports education program participated in the study group in 2017-2018 academic year. In this research, Teacher Leadership Scale (Beycioğlu and Aslan, 2010), Social Problem Solving Inventory (Dora, 2003) and Socio - demographic Data Form were used. The data obtained from the scales were analyzed with SPSS 20.0 package program. Personal information and inventory total scores and factor scores for the candidates were determined by determining the frequency (f) and percentage (\%) values. In order to determine the relationship between the scores obtained from the scales, Pearson Product Moment Correlation Analysis (r) and the scores obtained were applied multiple regression analysis $(\beta)$. As a result, while there is an advanced positive relationship between leadership and positive orientation subdimension of the problem, it has been determined that there is a negative relationship between the problem, negative orientation, impulsive / careless style and avoiding style sub dimensions. It can be said that planned studies aiming to reinforce leadership characteristics in educational environments can make students more equipped to solve social problems.
\end{abstract}

Original Article

Article Info

Received: 08.11 .2018

Accepted: 15.12 .2018

Online Published: 31.12 .2018

*Sorumlu yazar: Kenan KOÇ, E-mail: kenankoc@erciyes.edu.tr, 05056516313 


\section{GíRiş}

Grup üyelerini yönetebilen ve ulaşmak istedikleri noktaya gelmek için mücadele eden toplum içinde sosyalleşme gösterebilen kişilere lider denilmektedir. Liderler verimli teşkilatın gelişmesinde esas rolü oynamaktadırlar. Onlar insanları gerekli istikamete götürürler (Erol, 2001). Liderlik, insanların faaliyetleri vasıtasıyla amaçlara ulaşmak demektir. Bu herhangi bir şeyi yerine getirmek yahut maksada ulaşmak gerektiğinde ortaya çıkmaktadır (Geybullayev, 2002). Başka ifadeyle, kişileri etkisi altına alarak hedeflenen gaye ile amaçlar ışığında yol izleme süreci liderliktir (Güney, 2000). Eğitim açısından baktı̆̆ımızda ise; eğitim öğretimin kaliteli olması ancak iyi öğretmenler yetişmesi ile mümkündür. İyi ve kaliteli eğitim ise ancak lider öğretmenler sayesinde gerçekleşmektedir Öğretmen liderliği, sinıftaki eğitim-öğretim etkinliklerini öğrencilerin gelişim düzeylerine göre düzenleyebilme, öğrencileri isteyerek, dersin içinde yer almalarını sağlayarak ve paylaşımlarda bulunarak öğrenmeye ve kendilerini sürekli geliştirmeye yöneltebilme becerisini kapsamaktadır (Can, 2013).

İnsanlık için liderlik ne kadar önemli ise, liderlerin yetişmesi için de öğretmen liderliğinin önemi bir o kadar fazla olduğu düşünülmektedir. Liderlerin yetişebilmesi ve toplumlara mal edilmesinde öğretmenlerin rolünün baskın olduğu kaçınılmaz bir gerçek olarak görülmektedir. $\mathrm{Bu}$ nedenle de ilköğretimden üniversiteye kadar geçen süre içerisinde öğretmenlerin öğrenciler üzerindeki etkinliğinin çok fazla olduğu bilinmektedir. Öğretmenlere düşen görev ise bu süre zarfı içerisinde genç liderlerin yetiştirilebilmesine katkı sağlayabilmektir (Akbulut, 2017). Öğretmenlerin öğretimle ilgili bütün faaliyetlerde büyük bir rolünün olduğu yadsınamaz bir gerçektir. Bu nedenle de eğitim ve öğretimin en önemli parçalarından biri olan öğretmenlerin meslek bilgilerinin yanı sıra bazı temel niteliklere de sahip olması gerekir (Kazan ve Pepe, 2009). Bu niteliklerin başında öğretmen liderlik özelliği gelmektedir tüm branşlarda önemli olan liderlik özellikleri beden eğitimi öğretmenleri için ayrıca önemlidir. Beden eğitimi öğretmenlerinde bulunması gereken en önemli özelliklerin başında sahip oldukları liderlik davranışlarını sergileyebilmeleri gelmektedir (Durukan, 2003). Bundan dolayı da beden eğitimi öğretmenleri için liderlik verimli olabilmeleri anlamında önemli bir unsurdur. Diğer branş öğretmenlerinden farklı olarak beden eğitimi öğretmenleri öğretmenlik mesleğini icra etmenin yanı sıra antrenörlük ve ya yöneticilik de yapabilmektedirler (Ojeme, 1988). $\mathrm{Bu}$ noktada ilk olarak liderlik özelliğinin kazandırılmasında etkili olan unsurlar akla gelmektedir. Şüphesiz iyi bir lider öğretmenin sahip olması gereken niteliklerden bir tanesi sosyal problem çözme yeteneğidir. Liderlerin problem çözme becerileri arttıkça içinde bulundukları örgütsel yapının lidere olan inancının artacağı düşünülmektedir.

Sosyal problem çözme; bireyin gündelik akışta karşılaştığı sorunların üzerinden etkin ve uygun biçimde gelebilmesi için gerekli olan yolları tespit etme, keşfetme ve yaratma çabalarını içeren bilişsel-davranış̧̧ı süreç olarak tanımlanmaktadır. Sosyal problem çözme aynı zamanda genel sosyal becerinin kolaylaştırılmasına ve korunmasına katkıda bulunmak için genel bir başa çıkma stratejisi olarak da görülmektedir. Bu görüşe göre sosyal problem çözme, kişinin stresli durumlarla etkili bir biçimde başa çıkma becerisini artıran bilinçli, akılcı, çaba gerektiren ve amaca yönelik bir başa çıkma süreci olarak da 
değerlendirilebilmektedir (Ergin, 2009). Sosyal problem çözme teriminde kullanılan "sosyal" sıfatı problem çözme alanını sınırlayan bir sıfat değildir. Problem çözme halinin doğal sosyal çevre içerisinde meydana geldiğini, problem çözmenin hem bir sosyal öğrenme süreci hem de bir sosyal beceri olarak görüldügünü vurgulamak amacıyla kullanılmaktadır. Sosyal problem çözme araştırmaları, kişisel olan, olmayan problemleri, kişilerarası problemleri, küçük grup problemlerini ve insana dair akla gelebilecek her türlü problem ile ilgilenmektedir (Feyzioğlu, 2008).

Tüm bu bilgiler ışığında çalışmamızın amacı; öğretmen liderlik davranışı ile sosyal problem çözme arasındaki ilişkinin varlığını ve derinliğini incelemektir. Özellikle beden eğitimi öğretmen adaylarının liderlik vasıflarının meslek hayatlarında sık sık gerekli olacağı düşünüldüğünde araştırmamızın literatüre katkı sağlayacağı, alanın ilgililerine fikir vereceği düşünülmektedir.

\section{YÖNTEM}

\section{Araştırma Modeli}

Bu çalışmada, nicel araştırma yöntemlerinden genel tarama modeli kullanılmıştır. Bu model, çok sayıda elemandan oluşan bir evrende, evren hakkında genel bir yargıya varmak amacıyla evrenin tümü ya da ondan alınacak örneklem üzerinde yapılacak taramadır (Karasar, 1984).

\section{Çalışma Grubu}

Çalışma grubu Nevşehir Hacı Bektaşi Veli, Erciyes, Ahi Evran ve Dumlupınar Üniversitesinden 2017-2018 eğitim öğretim y1lında beden eğitimi ve spor öğretmenliği programında 1. 2. 3. ve 4. sınıflarında öğrenim gören 300 gönüllü öğrenci katılmıştır. Araştırma grubunu oluşturan öğrencilere ait kişisel bilgiler Tablo 1'de gösterilmiştir.

Tablo 1: Katılımcıların Sosyo-demografik Özellikleri

\begin{tabular}{|c|c|c|c|}
\hline & Değişken & $\mathbf{N}$ & $\%$ \\
\hline \multirow{2}{*}{ Cinsiyet } & Kadın & 114 & 38.0 \\
\hline & Erkek & 186 & 62.0 \\
\hline \multirow{3}{*}{ Yaş } & $18-21$ & 103 & 34.3 \\
\hline & $22-25$ & 125 & 41.7 \\
\hline & $26-29$ & 72 & 24.0 \\
\hline \multirow{4}{*}{ Üniversite } & Hacı Bektaş Veli & 73 & 24.3 \\
\hline & Erciyes & 77 & 25.7 \\
\hline & Ahi Evran & 81 & 27,0 \\
\hline & Dumlupınar & 69 & 23.0 \\
\hline \multirow{4}{*}{ Sinıf } & 1.sinif & 85 & 28.3 \\
\hline & 2.sinif & 72 & 24.1 \\
\hline & 3.sinif & 73 & 24.3 \\
\hline & 4.sinif & 70 & 23.3 \\
\hline \multirow{3}{*}{$\begin{array}{l}\text { Genel A ğırlıklı } \\
\text { Not Ortalaması }\end{array}$} & $1.25-1.99$ & 54 & 18.0 \\
\hline & $2.00-2.99$ & 164 & 54.7 \\
\hline & $3.00-4.00$ & 82 & 27.3 \\
\hline
\end{tabular}

Tablo 1'e bakıldığ zaman erkeklerin ortalaması \% 62 iken kadınların ortalaması \% 38 olarak görülmektedir. Yaş değişkeni incelendiğinde katılımcıların \% 34.3’ü 18-21 aralığında, \% 41.7'si 22-24 aralığında ve \%24'ü 24-26 yaştadır. Sınıf seviyelerine bakıldığında \%28.3'ü 1 . Sinıf, \%24.1'i 2. Sinıf, \%24.3'ü 3. Sinıf ve \%23.3'ü ise 4. Sinıf olarak görülmektedir. 
Üniversite dağılımı incelendiğinde \%24.3 Hacı Bektaş Veli, \%25.7 Erciyes, \%27 Ahi Evran ve \%23 Dumlupınar, genel ağırlıklı not ortalamasına bakıldığında ise katılımcıların \% 18 'i 1.25-1.99 aralı̆̆ında, \%54.7'si 2.00-2.99 aralığında ve \%27.3’ü 3.00- 4.00 aralığındadır.

\section{Veri Toplama Araçları}

Araştırmada öğrencilere uygulanan olan anketlerin uygulanması esnasında araştırmacının yanı sıra üniversitede görev yapan öğretim elemanları tarafından adayların her birine geniş bir zaman dilimi içerisinde, acele edilmeden, gerekli açıklamalar yapılarak, adaylar için sağlıklı bir değerlendirme süreci yaratılmaya çalışılmıştır. Ayrıca adayların rahat bir ortamda formları doldurmaları amacı ile uygun materyal ve çevre koşulları sağlanmıştır. Araştırmada kullanılan veri toplama araçları Öğretmen Liderlik Ölçeği, Sosyal Problem Çözme Ölçeği ve Sosyo demografik bilgi formu uygulanmıştır.

Öğretmen Liderliği Ölçeği: Beycioğlu ve Aslan (2010) tarafindan geliştirilen Öğretmen liderlik ölçeği, 25 maddeden oluşan 5'li Likert tipi bir ölçektir. Öğretmenlerin, öğretmen liderliğine ilişkin hem algı hem de beklentilerini ölçen iki boyutlu bir yapıdadır. Öğretmen Liderliği Ölçeği'nin (ÖLÖ) güvenirlik hesaplamaları için ölçeğin Cronbach-alpha iç tutarlık katsayısı ve test-tekrar test hesaplamaları yapılmıştır. Güvenirlik düzeyini belirlemek amacıyla elde edilen veriler üzerinden hesaplanan Cronbach-alpha iç tutarlık katsayısı beklenti için ".93" algı için ise ".95" olarak hesaplanmıştır. Test tekrar test analizlerinde Pearson korelasyon katsayısı beklenti boyutu için " $r=.80$ ", algı boyutu için ise "r=.87" olarak rapor edilmiştir (Beycioğlu ve Aslan, 2010). Mevcut araştırma için güvenirlik katsayısı "beklenti” boyutu için “.87”, "algı” boyutu için ise “.93” olarak tespit edilmiştir.

Sosyal Problem Çözme Envanteri: D'Zurilla ve Nezu (1990) tarafindan geliştirilen ölçme aracı 5'li dercelemeye sahiptir. Maydeu Olivares ve D'Zurilla (1996) tarafindan yeniden gözden geçirilen ölçme aracı, Dora (2003) tarafindan Türkçe'ye uyarlanmıştır. "Sosyal Problem Çözme Envanteri'nin (SPÇE)" orijinal formu 52 madde ve probleme olumlu yönelme, probleme olumsuz yönelme, akılcı problem çözme, içtepisel dikkatsiz yaklaşım ve kaçınmacı yaklaşım olmak üzere 5 alt boyuttan oluşmaktadır. Sosyal problem çözme envanterinden alınan yüksek puan daha yapıcı, daha etkili problem çözmeyi, buna karşıın alınan düşük puanlar ise sosyal problem çözme becerisinin, etkisiz olduğunu ifade etmektedir. Alt ölçeklerin her biri için yüksek iç tutarlık katsayıları .79 ile .95 arasında bulunmuştur. Üç hafta ara ile yapılan test tekrar test güvenirlik katsayıları üniversite öğrenci grubu için .68 ile .91 arasında bulunmuştur. Ölçekten alınan puanlar arttıkça kişi kendisini problem çözme açısından yetersiz görmektedir.

\section{Verilerin Analizi}

Kişisel Bilgi Formu, Liderlik ve sosyal problem çözme ölçeğinden elde edilen veriler ve kodlanarak bir istatistik programına girilmiş ve analizler bu program aracıllğı ile yapılmıştır. Adaylara ilişkin demografik özellikler ve envanter toplam puanları verilmiştir. Elde edilen puanların normallik dağılımı incelendiğinde çarpıklık basıklık değerleri $+1 /-1$ aralı̆ı̆ında olduğu tespit edilmiştir. Değerlerde normallikten aşırı sapmalar olmadığı için parametrik test istatistikleri uygulanmıştır. Büyüköztürk'e (2007) göre çarpıklık ve basıklık değerlerinin +1/1 aralığında yer almasının normallikten aşırı sapmalar olmaması şeklinde yorumlanmaktadır. 
Ölçeklerden elde edilen puanların arasındaki ilişkiyi ortaya koyabilmek için Pearson Momentler Çarpımı Korelasyon analizi (r) ve elde edilen puanlarının birbirinin yordayıcısı olup olmadı̆̆ını tespit edebilmek için Çoklu Regresyon analizi uygulanmıştır.

Tablo 2: Liderlik ve problem çözme puanlarının çarpıklık - basıklık ve shapiro- wilk testi anlamlılık düzey sonuçları

\begin{tabular}{lcccc}
\hline Altboyutlar & $\mathbf{N}$ & Çarpıklık & Basıklık & p \\
\hline Liderlik & 300 & .028 & -.507 & .060 \\
Probleme olumlu yönelim & 300 & -.543 & -.050 & .000 \\
Probleme olumsuz yönelim & 300 & -.576 & .131 & .000 \\
Rasyonel Problem Çözme & 300 & -.471 & -.313 & .000 \\
Dikkatsiz Dürtüsel Tarz & 300 & -.568 & -.254 & .000 \\
Kaçınan Tarz & 300 & -.536 & -.219 & .000 \\
\hline
\end{tabular}

\section{BULGULAR}

Tablo 3. Katılımcıların ölçeklerden aldığı puanların betimsel istatistiği

\begin{tabular}{lcccc}
\hline & N & Minumum & Maksimum & X \pm SD \\
\hline Liderlik & 300 & 43,00 & 77,00 & $60.47 \pm 7.01$ \\
Probleme olumlu yönelim & 300 & 40.00 & 120.00 & $53.83 \pm 8.27$ \\
Probleme olumsuz yönelim & 300 & 59.00 & 95.00 & $72.96 \pm 9.28$ \\
Rasyonel Problem Çözme & 300 & 37.00 & 99,00 & $52.97 \pm 7.92$ \\
Dikkatsiz Dürtüsel Tarz & 300 & 54.00 & 130,00 & $62.97 \pm 6.32$ \\
Kaçınan Tarz & 300 & 60.00 & 120,00 & $73.46 \pm 6.35$ \\
\hline
\end{tabular}

Tablo 3 incelendiğinde liderlik özelliği ortalamasının 60.47 olduğu hesaplanırken, probleme olumlu yönelim alt boyutunun ortalama puanı ortalamasının 13.83, probleme olumsuz yönelim ortalamasının 12.96, rasyonel problem çözme ortalamasının 12.97, dikkatsizdürtüsel tarz ortalamasının 12.97 ve kaçınan tarz ortalamasının 13.46 olduğu hesaplanmıştır.

Tablo 4. Öğrencilerin liderlik düzeyleri ile sosyal problem çözme düzeyleri arasındaki korelasyon katsayıları

\begin{tabular}{|c|c|c|c|c|c|c|c|}
\hline & & 1 & 2 & 3 & 4 & 5 & 6 \\
\hline \multirow{3}{*}{ Liderlik $^{1}$} & $\mathrm{r}$ & 1 & & & & & \\
\hline & $\mathrm{p}$ & & & & & & \\
\hline & $\mathrm{N}$ & 300 & & & & & \\
\hline \multirow{3}{*}{$\begin{array}{l}\text { Probleme olumlu } \\
\text { yönelim }\end{array}$} & $\mathrm{r}$ & $.175^{* *}$ & 1 & & & & \\
\hline & $\mathrm{p}$ & .002 & & & & & \\
\hline & $\mathrm{N}$ & 300 & 300 & & & & \\
\hline \multirow{3}{*}{$\begin{array}{l}\text { Probleme olumsuz } \\
\text { yönelim }\end{array}$} & $\mathrm{r}$ & $-.125^{*}$ & $.297^{* *}$ & 1 & & & \\
\hline & $\mathrm{p}$ & .030 & .000 & & & & \\
\hline & $\mathrm{N}$ & 300 & 300 & 300 & & & \\
\hline \multirow{3}{*}{$\begin{array}{c}\text { Rasyonel Problem } \\
\text { Çözme }\end{array}$} & $\mathrm{r}$ & -.080 & $.404^{* *}$ & $.309^{* *}$ & 1 & & \\
\hline & $\mathrm{p}$ & .170 & .000 & .000 & & & \\
\hline & $\mathrm{N}$ & 300 & 300 & 300 & 300 & & \\
\hline \multirow{3}{*}{ Dikkatsiz Dürtüsel Tarz } & $\mathrm{r}$ & $-.144^{*}$ & $.432^{* *}$ & $.413^{* *}$ & $.309^{* *}$ & 1 & \\
\hline & $\mathrm{p}$ & .013 & .000 & .000 & .000 & & \\
\hline & $\mathrm{N}$ & 300 & 300 & 300 & 300 & 300 & \\
\hline \multirow{3}{*}{ Kaçınan Tarz ${ }^{6}$} & $\mathrm{r}$ & $-.163^{* *}$ & $.266^{* *}$ & $.394^{* *}$ & $.413^{* *}$ & $.309^{* *}$ & 1 \\
\hline & $\mathrm{p}$ & .005 & .000 & .000 & .000 & .000 & \\
\hline & $\mathrm{N}$ & 300 & 300 & 300 & 300 & 300 & 300 \\
\hline
\end{tabular}

$* * \mathrm{p}<0.001$

Tablo 4 incelendiğinde liderlik ile probleme olumlu yönelme arasında $(r=.175, p<0.01)$ yüksek düzeyde pozitif yönde anlamlı ilişki bulunurken, liderlik ile probleme olumsuz 
yönelme $(\mathrm{r}=-.125, \mathrm{p}<0.05)$, dikkatsiz dürtüsel tarz $(\mathrm{r}=-.144, \mathrm{p}<0.05)$ ve kaçınan tarz arasında $(\mathrm{r}=-.163, \mathrm{p}<0.01)$ negatif yönde ilişki tespit edilmiştir.

Tablo 5. Öğrencilerin liderlik düzeylerinin sosyal problem çözme becerilerini yordamasına yönelik regresyon tablosu

\begin{tabular}{|c|c|c|c|c|c|c|c|c|}
\hline & & $\beta$ & $\mathbf{T}$ & $p$ & $\boldsymbol{R}$ & $R^{2}$ & $\mathbf{F}$ & $\mathbf{P}$ \\
\hline \multirow{6}{*}{ 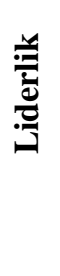 } & & & & & .226 & .051 & 3.163 & .008 \\
\hline & Probleme Olumlu Yönelim & .122 & 1.843 & .000 & & & & \\
\hline & Probleme Olumsuz Yönelim & -.025 & -.380 & .066 & & & & \\
\hline & Rasyonel Problem Çözme & .044 & .669 & .705 & & & & \\
\hline & Dikkatsiz Dürtüsel Tarz & -.073 & -1.066 & .504 & & & & \\
\hline & Kaçınan Tarz & -.120 & -1.871 & .287 & & & & \\
\hline
\end{tabular}

Tablo 5 incelendiğinde liderlik ile sosyal problem çözme becerisi arasında oluşturulan model anlamlı ilişki sunmaktadır $\left(\mathrm{R}=, 226 \mathrm{R}^{2}=, 051 ; \mathrm{p}<.005\right)$. Regresyon katsayısının anlamlılığına ilişkin $\mathrm{t}$ - testi sonuçları incelendiğinde probleme olumlu yönelim özelliğinin $(\mathrm{t}=1.843$, $\mathrm{p}=.000$ ) liderlik özelliğini yordadığı ve toplam varyansın \%51 'ini açıkladığı görülmektedir. $\left(\mathrm{F}_{(5,294)}=3.163, \mathrm{p}<.005\right)$.

\section{TARTIŞMA ve SONUÇ}

Araştırma sonuçları incelendiğinde liderlik ile probleme olumlu yönelim alt boyutu arasında pozitif yönde anlamlı ilişkiler olduğu tespit edilirken liderlik ile probleme olumsuz yönelim, dikkatsiz tarz ve kaçınan tarz arasında negatif yönde anlamlı ilişkiler olduğu tespit edilmiştir. Liderlik ile sosyal problem çözme becerisi arasında oluşturulan model varyansın \% 51'ini açıklamaktadır. Liderlik ile sosyal problem çözme arasında doğrusal bir ilişki olduğu görülmektedir.

Literatür incelendiğinde; Üstün'ün (2004) Türkiye'nin coğrafi bölgelerine göre beden eğitimi öğretmenlerinin liderlik özelliklerini belirlemek amacıyla yapmış olduğu tez çalışmasına tesadüfi örneklem metoduyla belirlenmiş 350 beden eğitimi öğretmeni katılmıştır. Araştırmadan elde edilen sonuçlara göre beden eğitimi öğretmenlerinin büyük çoğunluğunun liderlik özelliklerine sahip olduğunu rapor etmiştir.

Güllü ve Arslan (2009) yaptıkları çalışmada öğretmenlerin yarı demokratik liderlik stiline sahip olduklarını ve öğretmenlerin cinsiyetlerine, hizmet yıllarına, eğitim düzeylerine, okul düzeylerine ve okullarındaki öğrenci sayılarına göre liderlik stilleri arasında anlamlı bir fark bulanamazken öğretmenlerin çalıştıkları okullarının bulunduğu yerlere göre liderlik stilleri arasında anlamlı farklılıkların olduğu bulunmuştur.

Maxfield ve diğerleri (2008) okul yöneticisinin öğretmen liderliğinin gelişimindeki etkisini değerlendirmek için yaptıkları araştırmada, öğretmen liderliğinin gelişimindeki en büyük engelin, öğretmen liderliğinin yeterli düzeyde anlaşılmadığından kaynaklandığını belirtmişlerdir. Hurt (2015) öğretmen liderliği ve okul yapısının birbiriyle ilişkisinin olup olmadığını araştırmıştır. Bu çalışmaya öğretmenler, eğitim koçları gibi resmi öğretmen liderleri, danışmanlar gibi öğretim dışı personel ve yöneticiler katılmıştır. Bu çalışma iki ayrı literatür yapısının, yani okul yapısı ile öğretmen liderliğinin kesişmesi üzerinde durmaktadır. 
Araştırma bulguları öğretmene yetkiler veren okul yapısı ile öğretmen liderliğinin derecesi arasında orta düzeyde bir ilişki olduğunu, ayrıca katılımcıların okul seviyesi ile konumuna veya rolüne dayalı cevapları arasında farklılıklar bulunduğunu göstermektedir Patterson (2015) "Öğretmen Liderliğini Kolaylaştıran Başlıca Liderlik Davranışına İlişkin Öğretmen Perspektifleri” başlıklı araştırmasında ilkokul öğretmenlerinin neden liderliği üstlendiklerini ve liderler olarak onları destekleyen konuların neler olduğunu tespit etmiş̧tir. Elde edilen bulgulara göre genel olarak model olma, eğitimi sınıfın ötesinde etkileme arzusu, profesyonel gelişim, işbirliği, ağ oluşturma ve yönetme firsatları, ilkokul öğretmenlerinin öğretme sürecinde izlediği yolları etkilediği ortaya çıkmıştır. Bütün bu bulgular öğretmen liderlerin başkalarıyla olan bağlantılarıyla ilişkili bulunmuştur. Onların öğrencilerle, ailelerle ve/veya eğitimcilerle olan ilişkileri bunları yönetmeye sevk etmiş ve liderler olarak, kendilerine ilham kaynağı olmaya devam etmiştir. Doğan ve diğerleri (2016) üniversite öğrencilerine yaptıkları çalı̧̧mada liderlik ile kendine güven arasında anlamlı ilişkiler tespit etmiştir. Lunn (2006) "Öğretmen Profesyonelliği ve Liderliği Üzerine Bir Çalışma: Öğretmen Bakış Açısı" isimli çalı̧̧masında, nitel araştırma yöntemi kullanarak öğretmen profesyonelliği ve öğretmen liderliğini incelemiş ve iki olgu arasındaki ilişkiyi ortaya koymaya çalışmıştır. Araştırma sonucunda öğretmen profesyonelliği ile liderliği arasında yakın bir bağ olduğu, okullarda liderlik kapasitesinin geliştirilmesinin öğretmenin profesyonellik düzeyini artırdı̆̆ edilmiştir. Taylor ve diğerleri (2011) "Öğretmenlerin Profesyonel Gelişiminin Desteklenmesinde Öğretmenlerin Profesyonel Liderliği" isimli çalışmalarında tecrübeli öğretmenler için çeşitlendirilmiş profesyonel gelişim fırsatlarının sunulmasının, öğretmenin sınıf içi ve dışında güçlenmesini sağlayan liderlik kapasitelerinin değişimine destek olduğu ifade edilmiştir. Ayrıca yaygınlaştırılmış liderlik rollerinin profesyonel eğitimcilerin alanlarında uzmanlaşmasını ve eğitim reformlarının uygulanışının eş zamanlı olarak gelişimine olanak tanıdı̆̆ belirtilmektedir. Margolis ve Deuel (2009) "Aktif Öğretmen Liderliği: Motivasyon, Ahlak ve Para" adlı çalışmalarında öğretmenlerin liderliğini etkileyen her türlü yapıyı (ekonomik-duygusal) derinlemesine incelemişlerdir. Araştırma sonuçlarına göre öğretmen hem maddi olarak hem de manevi olarak destek gördüğü sürece mesleki ve bireysel olarak motive olmakta ve liderlik davranışları sergilemeye başlamaktadır. Öğretmen liderlerin öğretim süreçlerini değiştirme güçleri olduğunu ortaya koyan araştırma ile geleceğin öğretmenleri için söz konusu değiş̧kenlerin yeniden incelenmesinin gerekli olduğu belirtilmektedir. Turan, Erol ve Karaoğlu (2016) yaptıkları çalışmada öğretmen adaylarının liderlik düzeyleri ile öğretmenlik mesleği arasında anlamlı ilişkiler tespit etmiştir. Öte yandan sosyal problem çözme alanında; Konya'da öğrenim görmekte olan sınıf öğretmeni adayları üzerinde bir çalışma yapılmıştır. Sonuçlara göre öğretmen adaylarının öznel iyi oluşu ile sosyal problem çözme becerisi alt boyutları olan probleme olumlu yönelim ve rasyonel problem çözme arasında pozitif yönlü; öznel iyi oluş ile probleme olumsuz yönelim, kaçınma tarz ve dikkatsiz dürtüsüz alt boyutları arasında ise negatif yönlü bir ilişki bulunmaktadır (Yiğit, 2013). Heppner, Reeder ve Larson (1983), 500 üniversite öğrencisi üzerinde yüksek ve düşük problem çözme becerisi düzeyinin çeşitli bilişsel değişkenlerle ilişkisini incelemiştir. Elde edilen bulgular, kendini etkili problem çözücü olarak algılayan öğrencilerin diğerlerine göre bilişsel etkilerinden daha çok zevk aldıklarını, benlik algılarının yüksek ve kendini eleştirme puanlarının düşük olduğunu göstermiştir. Ayrıca bu öğrencilerin, fonksiyonel olmayan düşüncelere ve irrasyonel inançlara daha az sahip oldukları, başa çıkma 
yollarında daha az suçluluk duygusu yaşadıkları ve probleme daha fazla odaklanabildikleri tespit edilmiştir. Hamarta (2009) üniversite öğrencilerinin sosyal problem çözme, benlik saygısı ve yaşam doyumu arasındaki ilişkiyi incelemiştir. Araştırma sonuçları, benlik saygısı ve yaşam doyumunun probleme olumlu yönelme ve akılcı problem çözme ile pozitif, probleme negatif yönelme, iç tepkisel dikkatsiz problem çözme stili ve kaçıngan problem çözme stili ile negatif ilişkili olduğunu göstermiştir.

Liderlik vasfina sahip kişinin özelliklerine bakıldığında sosyal yönden güçlü, iletişime açık, kitleleri yönetebilen, diğergam insanlar olduğu görülmektedir. Sosyal problem çözme özelliği olan kişilerin ise sosyal becerilerinin (iletişime yatkın, etkileme becerisi olan, çatışma çözücü, işbirlikçi, ekip çalışmasına yatkın, liderlik yönü olan ve ilişki kuran insanlar (Baltaş ve Baltaş, 2002) olduğu görülmektedir.

Sonuç olarak; literatürdeki çalışmalar ve tanımlarda geçen ifadeler incelendiğinde liderlik özelliği yüksek düzeyde olan bireylerin kişiler arası (sosyal) problem çözme becerilerinin anlamlı düzeyde ve doğrusal yönde ilişkili olmasının doğal olduğu düşünülmektedir. Beden eğitimi ve spor öğretmenliği gibi sosyal yanının ve liderlik özelliğinin güçlü olması gereken branşlarda eğitim müfredatları düzenlenirken bu tarz kişilik özelliklerini geliştirici etkinliklere yer verilmesi meslek hayatına daha hazır hale gelmiş öğretmenler yetiştirmeye katk1 sağlayabilir.

\section{ÖNERILER}

- Problem günlük hayatımızın merkezinde yer alan bir kavramdır. Çalışmamızda liderlik ile sosyal problem çözme arasında ilişki incelenmiştir ancak farklı değişkenlerle ilişkiler incelenerek daha geniş yorum yapıllabilir.

- Yükseköğretim kurumlarında tüm bölümlerde liderlik ve problem çözme becerilerini geliştirici etkinlikler düzenlenebilir.

- Daha alt eğitim kademelerinden başlanarak liderlik ve kişiler arası problem çözme becerilerini geliştirici farkındalık çalışmaları yapılabilir.

- İdareciler, aileler ve alanın ilgilileri için ekstra etkinlikler düzenlenilerek paydaşlar bir araya getirilerek etkileşim sağlanabilir.

\section{KAYNAKLAR}

Akbulut, V. (2017). Öğretmen liderlik stiline göre ortaokul öğrencilerinin beden ĕgitimi yatkınlıklarının incelenmesi. (Yayınlanmamış) Yüksek Lisans Tezi. Karadeniz Teknik Üniversitesi, Trabzon.

Baltaş, A., ve Baltaş, Z. (2002). Stres ve başa çıma yolları. İstanbul: Remzi Kitabevi.

Beycioğlu, K., ve Aslan, B. (2010). Öğretmen liderliği ölçeği: Geçerlik ve güvenirlik çalışması. Elementary Education Online, 9, 2, 764-775. Erişim adresi: http://ilkogretim-online.org.tr/index.php/io/about.

Büyüköztürk, Ş. (2017). Sosyal bilimler için veri analizi el kitabı. Ankara: Pegem Akademi.

Can, N. (2013). Öğretmen liderliği. Ankara: Pegem Akademi. 
Koç, K. (2018). Beden eğitimi ve spor öğretmenliği adaylarının liderlik özellikleri ile sosyal problem çözme becerileri arasındaki ilişskinin incelenmesi. Spor Bilimleri Araştırmaları Dergisi, 3,(2), 223-232.

Doğan, D., Sucan, S., Turan, M.B., Pepe, O., \& Karaoğlu, B. (2016). The Relationship between leadership styles and assertiveness of physical education teachers. International Journal of Science Culture and Sport, 4, 1, 11-20.

Durukan, E. (2003). Selçuk Üniversitesi beden eğitimi ve spor yüksekokulu I. ve II. sınıf öğrencilerinin liderlik davranışlarının karşılaştırılması. (Yayımlanmamış) Yüksek Lisans Tezi. Selçuk Üniversitesi, Konya.

D'zurilla, T. J., \& Nezu, A. M. (1990). Development and preliminary evaluation of the social problem-solving inventory. Psychological Assessment a Journal of Consulting and Clinical Psychology, 2,2, 156-163. DOI: 10.1037/1040-3590.2.2.156.

Ergin, B. (2009). Kişilerarası problem çözme davranışı, yetişkinlerdeki bağlanma biçimleri ve psikolojik rahatsızlık belirtileri arasındaki ilişkiler. (Yayınlanmamış)Yüksek Lisans Tezi. Ankara Üniversitesi, Ankara.

Erol, E. (2001). Örgütsel davranışve yönetim psikolojisi. İstanbul: Beta Basım Yayın Dağıtım.

Feyzioğlu, E. (2008). Bağlanma stilleri, problem çözme becerileri ve hükümlülük arasındaki ilişski. (Yayınlanmamış) Yüksek Lisans Tezi. Sosyal Bilimler Enstitüsü, Ankara Üniversitesi, Ankara.

Geybullayev, G. (2002). Yönetimin esasları. Isparta: Süleyman Demirel Üniversitesi Yayınları, SDÜ Basımevi.

Güllü, M., \& Arslan, C. (2009). Leadership styles of physical education teachers. Mustafa Kemal Üniversitesi Sosyal Bilimler Enstitüsü Dergisi, 6, 11, 352-367.

Güney, S. (2000). Yönetim ve organizasyon el kitabı. Ankara: Nobel Yayın Dağıtım.

Hamarta, E. (2009). A Prediction of self-esteem and life satisfaction by social problem solving. Social Behavior and Personality, 37, 1, 73-82. DOI: 10.2224/sbp.2009.37.1.73.

Heppner, P. P., Reeder, B. L., \& Larson, L. M. (1983). Cognitive variables associated with personal problem- solving appraisal: implications for counselling. Journal of Counseling Psychology, 30, 1, 537-545. DOI: 10.1037/00220167.30.4.537.

Hurt, M. H. (2015). Investigating The Intersection of School Structure and Teacher Leadership: A Mixed-Methods Study. (Unpublished) Doctorate's Thesis. The Ohio State University, Columbus. Erişim adresi: https://etd.ohiolink.edu/pg_10?0::NO:10:P10_ETD_SUBID:102468\#abstract-files.

Karasar, N. (2007). Bilimsel araştırma yöntemi. Ankara: Nobel Yayın Dağıtım.

Kazan, Kırçık, Ş., ve Pepe, K. (2009). Burdur ilinde görev yapan beden eğitimi öğretmenlerinin mesleki sorunları üzerine bir araştırma. 6. Ulusal Beden Eğitimi ve Spor Öğretmenliği Sempozyumu’nda Sunulan Bildiri. Mehmet Akif Ersoy Üniversitesi, Burdur.

Lunn, J. M. (2006). A Study on teacher professionalism and teacher leadership: The teachers' viewpoint. Thesis, The University of Waikato, Hamilton, New Zealand. Erişim adresi: https://hdl.handle.net/10289/2296.

Margolis, J., \& Deuel, A. (2009). Teacher leaders in action: motivation, morality, and money. Leadership and Policy in Schools, 8, 3, 264-286. DOI: https://doi.org/10.1080/15700760802416115.

Maxfield, C., Wells, C., Keane, W., \& Klocko, B. (2008). The Role of superintendents in supporting teacher leadership. Journal of School Leadership, 20, 669-693.

Ojeme, E. O. (1988). Perceived and actual role of secondary school physical educators. Journal of Teaching in Physical Education, 8, 1, 33-45.

Patterson, E. L. (2015). Teacher perspectives of principal leadership behavior that facilitate teacher leadership. Unpublished Doctorate's Thesis. Roosevelt University, Chicago.

Taylor, M., Yates, A., Meyer, L. H., \& Kinsella, P. (2011). Teacher professional leadership in support of teacher professional development, Journal of Teaching and Teacher Education 27,1, 85-94. DOI: https://doi.org/10.1016/j.tate.2010.07.005.

Turan, M. B., Erol, Z., ve Karaoğlu, B. (2016). Beden eğitimi ve spor öğretmenliği bölümünde okuyan öğrencilerin liderlik düzeylerinin öğretmenlik mesleği gordama gücünün incelenmesi. I. Ü Spor Bilimleri Dergisi, 6, 3, 71-78. Erişim adresi: http://dergipark.gov.tr/download/article-file/340419. 
Koç, K. (2018). Beden eğitimi ve spor öğretmenliği adaylarının liderlik özellikleri ile sosyal problem çözme becerileri arasındaki ilişkinin incelenmesi. Spor Bilimleri Araştırmaları Dergisi, 3,(2), 223-232.

Üstün, F. (2004). Türkiye’nin coğrafi bölgelerine göre beden ĕgitimi öğretmenlerinin liderlik özelliklerinin belirlenmesi. (Yayınlanmamış) Yüksek Lisans Tezi. Selçuk Üniversitesi, Konya.

Yiğit, R. (2013). Öğretmen adaylarının öznel iyi oluşu ile sosyal problem çözme becerileri arasındaki ilişkinin incelenmesi. İlköğretim Online Dergisi, 12, 2, 550-560. Erişim adresi: http://dergipark.gov.tr/download/article-file/90499. 